\title{
Effective Teaching and Learning in Science Education through Information and Communication Technology [ICT]
}

\author{
Aina, Jacob Kola \\ Physics Department College of education (Technical) Lafiagi Kwara state, Nigeria
}

\begin{abstract}
Science education is the study of biology, chemistry or physics in conjunction with education in other to be able to teach science concepts and address students' misconceptions in science. Effectiveness of teaching and learning is required in science education through application of ICT. The paper reviewed various applications of ICT in effective teaching and learning of biology education, chemistry education and physics education; problems militating against full application of ICT in science education was highlighted. Suggestion was made for government to establish a well furnished ICT centre in all schools and many more.

Keywords: science education, ICT, computer, internet.
\end{abstract}

\section{Introduction}

Science education could mean different thing to different people but one thing that is sure is combining of science knowledge with the study of education. Science education therefore implies acquiring both scientific knowledge and education to be able to share this scientific knowledge with individual or community who are not traditionally in science. Better still, science education is the study of biology, chemistry or physics with method of teaching in other to be able to impart scientific knowledge to any individuals or community. The moment methodology is excluded from learning of biology, chemistry or physics it is no longer science education but only science. Science education should be able to teach science concepts and also address learners' misconceptions about these science concepts.

Science education is very important to technological development of any nation because of its numerous benefits (Omosewo, 2009; Awolaju, Akinloye and Ilori, 2010). Developed nations of the world are not taking science education with loosed hands; they invent on it and that is why they remain developed. For Nigeria to attain a position of developed nation we cannot afford to joke with the development of science education as the case is presently; there is the need for a positive change.

Nothing is static in the world again everything changes almost every second of the day; so should be educational activities (teaching and learning). Gone are the days when teaching and learning is only based on chalk and books packed somewhere called library; today everything has gone computerized to retrieved, store and transmit information.

Aina (2012) pointed that method of teaching has gone beyond traditional method of talk and chalk method no wonder Shedd (2004) has suggested that anyone preparing to become teachers must incorporate technology into their class.

To become great among the committee of nations Nigerian must change her method of teaching and learning of science education from traditional way of talk and chalk method and reading by carrying books around. The world is in the era of Information and Communication Technology [ICT] where information is not restricted by time, space and channel (Ajayi and Ojo, 2010); teaching and learning are not restricted to time, space and channel. Teaching and learning could be done in your bedroom, on the sea even in the air; teaching and learning is no longer restricted into classroom any more.

Now that students are losing interest in learning and the teachers are no longer committed (Awolaju, Akinloye, and Ilori 2010) to teaching; we need a modern way of teaching and learning so that student academic achievement in science can improve in all our institution. Science is dynamic, new discoveries are coming up every day both in science and in teaching method; we can only benefit from these new development when we are connected to the world through ICT. It is not an overstatement if one says "without ICT scientific knowledge would not be taught adequately in any school of the world", not surprising Olugbenga and Adebayo (2010) argued that ICT has become a central focus in many developed and developing countries.

Countries of the world such as Austria, Finland, Sweden, Denmark and UK, teachers and students have a generally positive attitude towards e-learning and relatively advanced IT competences (EU, 2005).

ICT is defined by Olugbenga and Adebayo (2010) as collection, retrieval, use and storage and communicating information through the use of computers and micro electronic system. UNESCO in Meleisea (2007) viewed ICT as a technology of creating, displaying, storing, manipulating and exchanging information.

Importance of ICT in our society today is enormous as underscored by Adebayo (2010) that ICTs is an indispensable part of contemporary society; allows access to information anywhere in the world; promote 
networking that is not restricted by boundary, language and culture; foster communities empowerment and spread knowledge. ICT offer citizens the mean to organize themselves and produce cultural codes to represent themselves (Ajayi and Ojo, 2010)

Absence of ICT in any educational system makes such educational system as old as centuries behind the present age that is why Dawodu and Macgregor-Odusanya (2010) pointed out that ICT has become an invaluable tool in contemporary world and in educational enterprise. It formed essential parts of the social and political framework of society (Ajayi and Ojo, 2010)

\section{Applications of ICT in science education}

There are many applications of ICT in teaching and learning depending on the knowledge of the user however, Collis and Moonen in Nguyen, Williams and Nguyen (2012) classification of these application in classroom teaching includes the learning resources, instructional organization of learning and communication. The classifications made use of educational software; computer- based testing system, e-mail system, internet, telephone, radio etc.

Generally ICT will be applicable in Computer Assisted Instruction [CAI]; Computed Aided Design $[C A D]$; Teleconferences and Library Computer System [LCS]. There are many other general applications of ICT in education apart from those mentioned above but this review will briefly discussed those mentioned before going to applications in specific subject.

\section{CAI}

Interactions among students and teachers can be presented on computers in the form of text or in multimedia forms; this could include photograph, videos, animations, speech and music. This program could involve questions posed to students, returned feedback and additional questions could follow based on the students' responses.

\section{CAD}

This is used to design a plan or a product which could be architecture in nature or in automobile (Dawodu and Macgregor-Odusanya 2010). This is commonly used in industry for mass production of scientific and other equipment to reduce cost of production, reducing energy and time in production.

\section{Teleconferences}

Teachers and students can view, take part in conferences and take part in a debate in the comfort of their offices or home through this medium. Through satellites, transmission of conference proceeding from far distance could be made available within few seconds without travelling at reduced expenses.

\section{LCS}

Many library are computerized in such a way that students and teachers need not to stress themselves searching for books in the shelves again. Many books and journals are already archived in the library database and any information on such books and journal could be retrieved in a matter of seconds.

\section{Applications in science education}

This section will look at ICT application in biology education, chemistry education and physics education separately.

\section{Applications in biology education}

Computers help students visualize objects that are difficult or impossible to view. For example, computers can be used to display human anatomy, internal structure of human and animal cells. Software are already developed which shows actions of viruses and bacteria which if teacher were to teach such; apart from the danger poses to both teacher's and student's health these micro organisms cannot be well learnt without seen them in action.

Law is already promulgated in some part of the world against killing animal for experimental purpose instead models and computer animation could be used by students for experiment in life science. Many plants in botany, animals in zoology and insects in entomology can never be found here in Nigeria, yet must be learnt by students; with ICT all these are made available to students as if they are in real forms.

CAI tools, like word processors, spreadsheets, and databases, is used to collect, organize, analyze, and transmit information. These tools also facilitate communication among students, between students and instructors, even beyond the classroom experience to distant students and instructors. 


\section{Applications in chemistry education}

Chemistry deals with chemicals and their reactions most of which are very dangerous to life if not handle with caution. Reactions of these chemicals in most cases are not easy to understand by students without seeing them in real term; teachers usually explain these reactions abstractly and through molecular diagram. CAI has been of tremendous help in solving this problem; software is available where students could watch this reaction on computer as in real life. Animations and videos of complex molecular structures in chemistry are available for classroom teaching for all categories of students in chemistry. For example students will find it difficult to appreciate the chemistry of atom if not supported using ICT; other area of chemistry that would be difficult to teach and learn if not supported by ICT are quantum theory, chemical reaction, ionization, electrochemistry and many more.

There are rate of reactions and graph that are so complex to teach by the teacher which ICT can help the teacher to manipulate for the student proper understanding. Many times information needed in chemistry class may not be available as at the time of the lesson; students or the teacher can access such information using internet facility at anytime.

\section{Applications in physics education}

Physics is regarded as an abstract subject by many people (Adeyemo, 2010); this may be because of the way the teacher teaches it. If concepts in physics are taught very well with the aid of ICTs nobody would call it abstract subject again; it is true some mechanism may be complex to explain but technology has solved the problem through educational software. Educational software can be used to teach difficult concepts or observe difficult skills in physics. For example teaching of electric generator in physics can be facilitated with the assistance of educational software. The rotation of the coil in the magnetic field is very clear when student see it demonstrated through this software. Most physics teachers could not explain the mechanism of electric generator to student properly because of its complexity; the teacher could use projector and computer to allow students view action of electric generator by a large physics class.

Information on text, picture, tables and graph are presented to students using ICT especially to visualize a complex process in physics teaching. When this information is presented students can manipulate it to make changes and at the same time evaluate the changes made.

Feedback is very important in teaching and learning process (Aina \& Adedo, 2013) because it improve student learning. This could be done through computer. For example CAI tools like word- processor and spreadsheet help student to learn how to spell words correctly, when text is being underlined by the computer. Without the presence of a teacher student can learn any activity prepared for that period through already programmed work in a system. Students can improve their learning when they spend quality time working or practising any skill already learnt on the computer.

Generally, applications of ICT in science education are so many; the limit to these applications is a matter of knowledge; the more knowledgeable someone is in ICT the more he or she will be able to apply it.

Teacher is able to send class activities and assignment through mobile phone like in business world. Subscribing to bundles of SMS can help teacher to reach hundreds of students at a time; this method could be employed when the teacher is not even present in the class and could afford student the opportunity of working at their own pace.

Learning activities are communicated through e-mail system nowadays (Nguyen, Williams \& Nguyen 2012). Teacher could be in a far distance away from school and still perform his/her duty sending learning activities through e-mail.

Both teacher and student can communicate together outside classroom situation through internet. Learning activities are sent to student and the student will respond once they are connected online; this is the principle behind online degree many possesses today.

\section{Problem militating against application of ICT in science education}

As good as ICT might seem to be to any nation yet there are some problems militating against its application even in developed countries of the world. Therefore the problems highlighted below might not be peculiar to Nigeria alone.

\section{Inadequate funding}

The money needed for full ITC compliance is huge and this fund is not available because of economic situation of the country. Equipment like computers, projectors and internet facility are required; these materials are very costly to purchase by any school except there is external aids. Government is not sincere to quality education of the citizens this is reflected in the annual budget of the government. Akindutire (2010) observed that Nigeria government has not met the UNESCO recommendations of $26 \%$ of the total budgetary allocation to education sector as reflected in her yearly budget. 


\section{Teachers' factors}

Majority of science teachers are not computer literate and have remained in that condition for long time without seminar, conference, workshop and refresher course in computer. The best way to say this is that there is shortage of certificated computer teacher in our schools (Ajayi and Ojo, 2010). Many of the few computer teachers available don't have personal computer either because their low income could not afford one or they did not see the need for it.

\section{Corruption and insecurity}

There is high level of corruption and insecurity in the nation (Olagunju, 2012; Aina, 2012) this is affecting every aspect of life of Nigerians including education. Money meant for the purchase of educational equipment are mismanaged and misappropriated by government officials. When government awards contracts for the purchase of school equipment like computers and the like; it is not done or executed poorly yet millions of naira must have gone into these contracts. Insurgents and kidnappers have destroyed infrastructures meant for teaching and learning in schools while many teachers have been kidnapped and killed at his duty post. All these have created fear for teachers and they are not ready to come out of their home for computer seminar, workshop, conference and refresher course just anywhere in the country; they remain as they were for many years.

Lack of stable power supply

Nigeria is a country where electric power supply is probably the worst among developing nations. Electric power supply is not reliable in the country therefore anything that make use of electric power will surely have problem like ICT. All government effort to solve the problem has not yield good result.

\section{Conclusion and recommendations}

Science education is not just going to school to study biology, chemistry or physics but study of these subjects in conjunction with education. ICT is good for effective teaching and learning in science education; ICT have many applications in science education that can facilitate learning of difficult concepts in biology, chemistry and physics. However, there are problems militating against the full application of ICT in science education; based on this conclusion the following suggestions are recommended:

- ICT centre should be established in all schools and fund be made available to purchase computers and other ICT equipment;

- More trained computer teachers should be employed and those science teachers who are not computer literate should be mandated to go for computer training;

- Government should make it mandatory for science and computer teachers to always; attend seminar, workshop, conference and refresher course in computer;

- Government should provide more jobs for young unemployed graduates as a measure of security for the nation;

- There should be a serious punishment for any individual or group who mismanaged or misappropriate money meant for education;

- Government should provide all science teachers with laptop;

- Government should work hard to solve problem of power failure in the country.

\section{References}

[1]. Adebayo, S.A. (2010). Meeting the challenges of special education through ICT as a means of achieving sustainable development in Nigeria. South- West Journal of Teacher Education, 3, 299-308

[2]. Adeyemo, S.A. (2010). Teaching/ learning physics in Nigerian secondary school: The curriculum transformation, issues, problems and prospects. International Journal of Educational Research and Technology, 1 (1),99-111

[3]. Aina, J.K. (2012). Factors affecting students' performance in science in Nigeria schools Retrieved from http://www.amazines.com/article detail.cfm?articleid $=4246692$

[4]. Aina, J. K. (2012). Security Challenges in Nigeria: Causes and effects on Science Education Developmenthttp://www.basearticles.com/Art/932483/39/SECURITY-CHALLENGES-IN-NIGERIA:-CAUSES-AND-EFFECTS-ONSCIENCE-EDUCATION-DEVELOPMENT.html

[5]. Aina, J. K \& Adedo, G.A. (2013). Correlation between continuous assessment (CA) and Students' performance in physics. Journal of Education and Practice. 4(6), 6-9

[6]. Ajayi, I. A \& Ojo, F.F. (2010). Information and communication technology: a catalyst for democratized system of government. South- West Journal of Teacher Education, 3, 692-708

[7]. Akindutire, I.O. (2010). Teacher education in democratic Nigeria: challenges and the way forward. South- West Journal of Teacher Education, 3, 107-128

[8]. Awolaju, B.A., Akinloye, O.O., Ilorin, O.J. (2010). Science education in democratized Nigeria: challenges and the way forward. South- West Journal of Teacher Education, 3, 615-622

[9]. Dawodu, R.A., Macgregor-Odusanya, O.O. (2010). Information and communication Technology: a new approach in vocational and technical education in a democratized Nigeria. South- West Journal of Teacher Education, 3, 709-718

[10]. European Union (2005). The use of ICT for learning and teaching initial vocational education and training. Final report to the EU Commission, DG Education and Culture. 
[11]. Meleisea, E. (2007). The UNESCO ICT in education program. Bangkok, Thailand: United Nations, Education, Scientific and Cultural Organization.

[12]. Nguyen, N, Williams, J \& Nguyen, T. (2012). The use of ICT in teaching tertiary physics: echnology and pedagogy. Asia-Pacific Forum on Science Learning and Teaching.13 (2) Article 6,1

[13]. Olagunju, O. (2012). Corruption control in Nigeria: Holistic approach. Education development Institute, 2(1), 76-84

[14]. Olugbenga, O.V., \& Adebayo, O.L. (2010). Enforcing ICT knowledge on students as a means of enhancing academic performance in a democratized society: counselling and management perspective. South- West Journal of Teacher Education, 3, 376-400

[15]. Omoesewo E.O. (2009). Views of physics teachers on the need to train and retrain hysics teachers in Nigeria, African Research Review, 3 (1), 314-325

[16]. Shedd, J. (2004). Incorporating technology in the classroom. A Publication of the School Of Education, Syracuse university USA: Education Exchange 